\begin{tabular}{|c|c|c|}
\hline \multirow[b]{2}{*}{ एव, } & Int.J.Curr.Microbiol.App.Sci (2021) 10(11): 340-345 & \\
\hline & $\begin{array}{l}\text { International Journal of Current Microbiology and Applied Sciences } \\
\text { ISSN: 2319-7706 Volume } 10 \text { Number } \mathbf{1 1} \mathbf{( 2 0 2 1 )} \\
\text { Journal homepage: http://www.ijcmas.com }\end{array}$ & 30 \\
\hline $\begin{array}{l}\text { EXCELLENT } \\
\text { PUBLISHERS }\end{array}$ & & \\
\hline
\end{tabular}

\title{
Constraints and Suggestions of the Cotton Growers in Vidharba for Adoption of Improved Integrated Management Practices of Pink Bollworm
}

\author{
Aruna Katole*, N. M. Kale and V. S. Tekale \\ Department of Extension Education, Dr. Panjabrao Deshmukh Krishi Vidyapeeth, \\ Akola-444104, M.S., India \\ *Corresponding author
}

\section{Keywords}

Constraints, Improved integrated management practices of pink bollworm,

Suggestions

\section{Article Info}

Received: 12 October 2021 Accepted: 03 November 2021 Available Online: 10 November 2021

\section{A B S T R A C T}

The pink bollworm (PBW) is an insect known for being a pest in cotton farming. In Maharashtra cotton growers are set to lose nearly $13 \%$ of their output due to pink bollworm attacks on the standing crop in major production regions of the state. The impact of PBW attack has been felt the most in regions of vidarbha where cotton is cultivated as the main cash crop. Present study was conducted in six districts of Vidarbha region in Maharashtra considering the maximum area under cotton cultivation namely Buldana, Akola, Amravati, Yavatmal Wardha and Nagpur. A sample of 300 cotton growers were randomly selected from twelve taluka (two taluka from each district).The major constraints faced by cotton growers were non availability of labourers and high wage rate for undertaking the manual work of handpicking of larvae destruction of affected fruiting bodies and removal of rosette flower $(95.00 \%)$, non availability of biofungicides Beauveria bassiana at nearby market (90.33\%), non availability of good quality pheromone trap \& good quality pheromone lure $(89.00 \%)$. In case of suggestions expressed by cotton growers overcome constraints were availability of biofungicides Beauveria bassiana should made available at subsidized rate nearby market, followed by availability of recommended insecticides should made available at subsidized rate in nearby market (94.33\%), the government should made available good quality pheromone trap and lure used for pink bollworm at village level $(93.00 \%)$, credit facilities should be increased and process should also easy and quick $(87.33 \%)$.

\section{Introduction}

Cotton is the most important crop producing natural fiber which has been under commercial cultivation for domestic consumption and export needs of about 111 countries in the world and hence called "King of fibers" or "White gold". India is an important grower of cotton on a global scale. In India, cotton is cultivated in an area of 126.55 lakh ha. is the largest cotton area in the world. But while India ranks first in total area of cotton cultivation, it ranks third in total cotton production because of the low yield per 
acre. Maharashtra is a traditional producer of cotton. Over 80.00 per cent of the production comes from Khandesh, Vidarbha and Marathwada regions comprising the districts of Yavatmal, Nanded, Amravati, Parbhani, Wardha, Jalgaon, Akola, Buldhana, Nagpur, Dhule, etc. About 3 million farmers are engaged in cotton cultivation in the state mostly in backward regions of Marathwada and Vidarbha. Although, Maharashtra is the largest cotton growing State and ranks second in cotton production in the country, produces $22.82 \%$ of the total cotton production of India during 2018-17. A major limiting factor for cotton production in India is the damage due to insect pests especially bollworms. Among the bollworm complex, worldwide pink bollworm (PBW) has become economically the most destructive pest of cotton. The pink bollworm is an insect known for being a pest in cotton farming. It consume the fiber and seeds inside cotton plants boll and causing heavy economic loss. In India, the loss of cotton yield due to bollworm was estimated to be around 50\% - 60\%. (Narayana and Ramaswami, 2007). In Maharashtra cotton farmers are set to lose nearly $13 \%$ of their output due to pink bollworm attacks. The Vidarbha is the highest producer of cotton in the state. Since past 2-3 years, pink bollworm has become a major problem in cotton. Since from last two years Dr. Punjabrao Deshmukh Krishi Vidyapeeth, Akola, KVKs and State Department of Agriculture collaboratively conducted massive campaign for pink bollworm and made special efforts regarding dissemination of improved integrated management practices of pink bollworm to destruction of pink bollworm damage and obtaining maximum profit in cotton crop in Vidarbha region of Maharashtra. Hence it was necessary to find out what constraints faced by the cotton growers in adoption of improved integrated management practices of pink bollworm and what suggestions expressed by them to overcome the constraints.

\section{Materials and Methods}

The study was conducted in six districts of Vidarbha region in Maharashtra considering the maximum area under cotton cultivation namely Buldana, Akola, Amravati, Yavatmal Wardha and Nagpur by conducting field survey with Ex-post-facto research design of social research. For the proposed study, from six selected district total twelve taluka (two taluka from each district) were purposively selected on the basis of maximum area under cotton cultivation. From each selected taluka five villages and from each selected villages five cotton growers were selected randomly. Thus, total three hundred cotton growers (twenty five from each taluka and fifty from each district) constituted as sample of the study.

The data were collected personally by the researcher using pretested interview schedule. It was analysis on the basis of frequency and the percentage of each constraint was worked out to measure the constraints faced by the cotton growers.

\section{Results and Discussion}

\section{Constraints faced by the cotton growers in adoption of improved integrated management practices of pink bollworm}

In the present context, the term constraint means as the problem, difficulties face by the cotton growers in adoption of improved integrated management practices of pink bollworm. The constraints expressed by the cotton growers in adoption of improved management practices of pink bollworm are listed in Table 1 in terms of their frequency and percentage. The data presented in Table 1 revealed that majority of the cotton growers $(95.00 \%)$ faced constraints of non availability of labourers and high wage rate for undertaking the manual work of handpicking 
of larvae destruction of affected fruiting bodies and removal of rosette flower, it was followed by non availability of biofungicides Beauveria bassiana at nearby market $(90.33 \%)$, non availability of good quality pheromone trap \& good quality pheromone lure $(89.00 \%)$, lack of knowledge about use of biofungicides Beauveria bassiana (86.33\%).

Whereas, near to four fifth of them faced problem of high labour wages and non availability of labour at proper time $(79.00 \%)$, non availability of credit facilities $(77.00 \%)$. While near to three fourth of them faced constraints of non availability of recommended insecticides at nearby market (74.33\%), mis-guidance from input dealers regarding chemical insecticides $(69.66 \%)$ and near to two third of cotton growers constraints mention as non availability of trichocards at village level (65.00\%), high cost of insecticides $(62.33 \%)$. However, over an half cotton growers expressed constraints of non availability of cattle for grazing of the left over green bolls on the plant at the end of crop season $(53.66 \%)$, crop rotation practices practically not possible due to limited land holding $(43.66 \%)$.

Table.1 Constraints faced by the cotton growers in adoption of improved integrated management practices of pink bollworm

\begin{tabular}{|c|c|c|c|}
\hline \multirow{2}{*}{$\begin{array}{l}\text { SI. } \\
\text { No. }\end{array}$} & \multirow[t]{2}{*}{ Constraints } & \multicolumn{2}{|c|}{ Respondents $(\mathrm{n}=\mathbf{3 0 0})$} \\
\hline & & Frequency & Percentage \\
\hline 1. & $\begin{array}{l}\text { Non availability of cattle for grazing of the left over green bolls } \\
\text { on the plant at the end of crop season. }\end{array}$ & 161 & 53.66 \\
\hline 2. & Deep ploughing make the soil more lose and is not economical. & 33 & 11.00 \\
\hline 3. & Intercrop practices not possible due to wild animals. & 63 & 21.00 \\
\hline 4. & $\begin{array}{l}\text { Crop rotation practices practically not possible due to limited } \\
\text { land holding. }\end{array}$ & 131 & 43.66 \\
\hline 5. & Non availability of trichocards at village level. & 195 & 65.00 \\
\hline 6. & $\begin{array}{l}\text { Non availability of good quality pheromone trap \& good quality } \\
\text { lure for pink bollworm moth. }\end{array}$ & 267 & 89.00 \\
\hline 7. & $\begin{array}{l}\text { Non availability of labourers and high wage rate for undertaking } \\
\text { the manual work like handpicking of larvae destruction of } \\
\text { affected fruiting bodies and removal of rosette flower. }\end{array}$ & 285 & 95.00 \\
\hline 8. & Lack of knowledge about recommended insecticides. & 113 & 37.66 \\
\hline 9. & $\begin{array}{c}\text { Non availability of recommended insecticides at nearby } \\
\text { market. }\end{array}$ & 223 & 74.33 \\
\hline 10. & $\begin{array}{l}\text { Lack of knowledge about use of biofungicides Beauveria } \\
\text { bassiana. }\end{array}$ & 259 & 86.33 \\
\hline 11. & $\begin{array}{l}\text { Non availability of biofungicides Beauveria bassiana at nearby } \\
\text { market. }\end{array}$ & 271 & 90.33 \\
\hline 12. & High cost of insecticides. & 187 & 62.33 \\
\hline 13. & Non availability of credit facilities & 231 & 77.00 \\
\hline 14. & Non availability of sprayer at proper time. & 77 & 25.66 \\
\hline 15. & High labour wages and non availability of labour at proper time. & 237 & 79.00 \\
\hline 16. & Mis-guidance from input dealers regarding chemical insecticides. & 209 & 69.66 \\
\hline
\end{tabular}


Table.2 Suggestions expressed by the cotton growers to overcome the constraints in adoption of improved integrated management practices of pink bollworm

\begin{tabular}{|c|c|c|c|}
\hline \multirow{2}{*}{$\begin{array}{l}\text { Sl. } \\
\text { No. }\end{array}$} & \multirow[t]{2}{*}{ Suggestions } & \multicolumn{2}{|c|}{ Respondents $(\mathrm{n}=300)$} \\
\hline & & Frequency & Percentage \\
\hline 1. & Availability of trichocards should be made at village level. & 200 & 66.66 \\
\hline 2. & $\begin{array}{c}\text { Demonstration on installation of pheromone traps, application of yellow sticky } \\
\text { traps, and technique of sowing refugia (non Bt) should be organized by } \\
\text { extension agencies. }\end{array}$ & 151 & 50.33 \\
\hline 3. & $\begin{array}{l}\text { The government should made available good quality pheromone trap and lure } \\
\text { used for pink bollworm at village level. }\end{array}$ & 279 & 93.00 \\
\hline 4. & $\begin{array}{c}\text { Demonstrations may organized by the concerned extension agency about } \\
\text { identification of rosette-bloom or rosette-flower", removal of rosette flower } \\
\text { and destruction of larva }\end{array}$ & 110 & 36.66 \\
\hline 5. & $\begin{array}{l}\text { Availability of recommended insecticides should made available at } \\
\text { subsidized rate nearby market. }\end{array}$ & 283 & 94.33 \\
\hline 6. & $\begin{array}{l}\text { Availability of biofungicides Beauveria bassiana should made available at } \\
\text { subsidized nearby market. }\end{array}$ & 288 & 96.00 \\
\hline 7. & Credit facilities should be increased and process should also easy and quick. & 262 & 87.33 \\
\hline 8. & $\begin{array}{c}\text { Availability of sprayer pump should made available at village level through } \\
\text { custom hiring centre }\end{array}$ & 53 & 17.66 \\
\hline 9. & $\begin{array}{l}\text { Free distribution of publication about improved integrated management } \\
\text { practices of pink bollworm should be provided. }\end{array}$ & 237 & 79.00 \\
\hline 10. & $\begin{array}{l}\text { Knowledge should be provided on preparation of insecticides solution and } \\
\text { proper precautions should be taken during use of insecticides. }\end{array}$ & 105 & 35.00 \\
\hline 11. & $\begin{array}{c}\text { Government check should be increase on insecticides dealer to sell appropriate } \\
\text { insecticides. }\end{array}$ & 205 & 68.33 \\
\hline
\end{tabular}

Furthermore, from the Table 1 observed that more than one third of the cotton growers mention the constraints lack of knowledge about recommended insecticides $(37.66 \%)$, followed by non availability of sprayer at proper time $(25.66 \%)$, growing intercrop practices not possible due to wild animal $(21.00 \%)$. While, less proportion of them faced constraints of deep ploughing in summer make the soil more lose and is not economical $(11.00 \%)$.

Suggestions expressed by the cotton growers to overcome the constraints

An attempt was made to ascertain suggestions from cotton growers to overcome various constraints faced by them in adoption of improved integrated management practices of pink bollworm. The cotton growers were requested to offer their valuable suggestions against difficulties faced by them in adoption of improved integrated management practices of pink bollworm and the responses received from cotton growers were noted. The responses received from cotton growers were noted and are presented in Table 2.

From Table 2 it is observed that out of 300 cotton growers majority $(96.00 \%)$ of the cotton growers suggested that availability of biofungicides Beauveria bassiana should made available at subsidized rate nearby market, followed by availability of recommended insecticides should made available at subsidized rate in nearby market $(94.33 \%)$, the government should made available good quality pheromone trap and lure used for pink bollworm at village level (93.00\%), credit facilities should be increased and process 
should also easy and quick (87.33\%), free distribution of publications about improved integrated management practices of pink bollworm should be provided $(79.00 \%)$, the government check should be increase on insecticides dealer to sell appropriate insecticides $(68.33 \%)$, availability of trichocards should be made at village level $(66.66 \%)$, demonstration should be organized by extension agencies on installation of pheromone traps, application of yellow sticky traps $(50.33 \%)$ and about identification of "rosette-bloom or rosette-flower", removal of rosette flower and destruction of larva (36.66\%), knowledge should be provided on preparation of insecticides solution and proper precautions should be taken during application of insecticides (35.00\%) availability of sprayer pump should made available through custom hiring centre at village level (17.66\%).

The major constraints faced by the cotton growers in adoption of management practices of pink bollworm were due to non availability of necessary agriculture input required for cotton cultivation and management practices of PBW at villages or nearby vicinity such as non availability of biofungicides Beauveria bassiana, good quality pheromone trap \& good quality pheromone lure, non availability of recommended insecticides, non availability of trichocards. While other constraints have faced by cotton growers due to their lack of knowledge of regarding management practices like lack of knowledge about use of biopesticides Beauveria bassiana. However, other constraints has been come due to situational factors such as non availability of cattle for grazing of the left over green bolls, limited land holding, non availability of credit facilities and wild animal problem.

In case of suggestion, it also concluded that in order to overcome the said constraints some suggestions were given by the cotton growers expressed that availability of biofungicides
Beauveria bassiana should made available at subsidized in nearby market, availability of recommended insecticides should made available at subsidized rate in nearby market, credit facilities should be increased and process should also easy and quick and free distribution of publications about improved integrated management practices of pink bollworm should be provided.

\section{References}

Aglawe D. D, Ekale J. V, Chavhan P. N and Bhute N. K. 2019. Constraints and suggestions of the cotton growers for effective implication of integrated pest management technology. International Journal of Chemical Studies. 7(6): 269-272.

Ghuge, B. Y., 2019. Adoption of Integrated Pest Management for controlling pink bollworm by Bt. cotton growers. M.Sc. (Agri.), Thesis (Unpub.), Vasantrao Naik Marathawada Krishi Vidyapeeth, Prabhani, Maharashtra.

Kale, N. M., P. P. Wankhede, D. M. Mankar, M. B. Dhole and A. V. Kolhe, 2018. Knowledge and Adoption of Cotton growers about Integrated Management Practices of Pink Research Review Committee Report 2018, Dr. Panjabrao Deshmukh Krishi Vidyapeeth, Akola (M.S.). pp 35-37.

Khodake, S. B., 2019. Management practices adopted by BT cotton growers for control of pink bollworm. M.Sc. (Agri.), Thesis (Unpub.), Dr. PDKV, Akola.

Narayanan, Lalitha and Bharat Ramaswami, 2007. Pesticides Use Pattern among Cotton Cultivators in Gujarat, Frontiers of agricultural development in Gujarat, Ravindra Dholakia (ed), Centre for Management in Agriculture, Indian Institute of Management: Ahmedabad. pp 77-98.

Shital D. Mane, 2019. Adoption of integrated pest management practices for control of pink bollworm by cotton growers. M.Sc. (Agri.), Thesis (Unpub.), Dr. PDKV, Akola. 


\section{How to cite this article:}

Aruna Katole, N. M. Kale and Tekale, V. S. 2021. Constraints and Suggestions of the Cotton Growers in Vidharba for Adoption of Improved Integrated Management Practices of Pink Bollworm. Int.J.Curr.Microbiol.App.Sci. 10(11): 340-345. doi: https://doi.org/10.20546/ijcmas.2021.1011.038 